\title{
Reform and Practice of Building Engineering Technical Professional Talents Training Under " $1+X$ " Certificate System-Taking BIM Certificate as a Case Study
}

\author{
Wei Liu ${ }^{1, *}$
}

\author{
${ }^{1}$ Binzhou Polytechnic, Binzhou, 256603, China \\ *Corresponding author. Email: 249191038@qq.com
}

\begin{abstract}
Taking building information modeling (BIM) certificate as an example, this work deeply explored the reform scheme and practice path of building engineering technical professional talents training under the " $1+\mathrm{X}$ " certificate system. By optimizing the scheme of building engineering technical professional talents training under the " $1+X$ " certificate system, the course system of "course and certificate integration" corresponding to the " $1+X "$ certificate system was reconstructed. Colleges and enterprises jointly built a comprehensive training platform based on BIM construction process, and reformed the teaching mode of "module + synthesis, level promotion", thus continuously improving the quality of professional talents training. Keywords: " $1+X^{\prime \prime}$ certificate system; BIM; Talent training; Course and certificate integration
\end{abstract}

\section{INTRODUCTION}

In January 2019, the State Council issued the "national vocational education reform implementation plan" (hereinafter referred to as "20 articles of vocational education"). Among them, article 6 put forward that "it should deepen the training mode reform of compound technical talents, draw lessons from the common practice of international vocational education and training, formulate the work plan and specific management measures, and start the pilot work of ' $1+X^{\prime}$ certificate system". Exploring and implementing the " $1+X^{\prime \prime}$ certificate system pilot is an important reform plan and a major innovation in the "20 items of vocational education". In April 2019, the Ministry of Education and other four ministries and commissions jointly issued "the notice on the pilot plan for implementing the system of 'academic certificate + several vocational skill level certificates' in colleges and universities". On June 17, 2019, the Institute of Vocational and Technical Education Center issued "the announcement on the list of the first batch of ' $1+X^{\prime}$ certificate system pilot institutions". Among them, a total of 1988 pilot institutions were approved 6 certificates in 5 fields. BIM is one of the first batches of certificates to be launched.

Since the pilot work of "1 $+X "$ certificate system, domestic colleges and universities have carried out exploratory research on the effective integration of "1" and "X". Among them, the talent training mode under the background of " $1+\mathrm{X}$ " certificate system and the issue of "course and certificate integration" are the hot spots of research.

Binzhou Polytechnic, as the first batch of BIM vocational skill level assessment sites, actively explores the talent training reform scheme under the " $1+X$ " certificate system while carrying out the pilot work of " $1+X^{\prime}$ certificate system. Also, it optimizes the training program of professional talents, and reconstructs the course system of "course and certificate integration" corresponding to the $" 1+\mathrm{X}$ " certificate. Colleges and enterprises jointly build a comprehensive training platform based on BIM construction process, and reform the teaching mode of "module + synthesis, level promotion". Vocational skill level assessment should be integrated into the whole process of talent training to promote the organic connection between " 1 " and "X".

\section{REFORM MEASURES OF BUILDING ENGINEERING TECHNICAL PROFESSIONAL TALENTS TRAINING UNDER "1+X" CERTIFICATE SYSTEM}

\subsection{Optimizing the scheme of building engineering technical professional talents training}

According to the skill requirements of " $1+X "$ BIM certificate for building information model, the "four-step" strategy was adopted to optimize the talent training program for building engineering technology majors. The first step is for enterprises to subdivide the content of jobs, and formulate corresponding job skill standards and assessment requirements respectively. The second step is the post skill certificate set for enterprises. The school gradually subdivides the skills and integrates them into the professional curriculum education. The third step is for 
students to enter the enterprise for internships, and accept the work assessment and evaluation of the enterprise. The fourth step is for enterprises to further optimize the requirements of post skill certificates and feed them back to schools according to students' ability performance, thus continuously promoting the optimization and adjustment of talent training programs and curriculum standards [4].

\subsection{Constructing the course system of "course and certificate integration"}

"Course and certificate integration" integrates the BIM " $\mathrm{X}$ " certificate certification into the course system of building engineering technology major, realizing the "integration" of course development and certificate standards. By integrating the BIM certification course contents of Glodon Software, Luban-Era, Pinming and other companies into the course system, the connotation requirements of "1+X" certificate system are continuously infiltrated into the course, thus achieving the in-depth combination of course contents and certificate contents.

According to the requirements of " $1+X "$ certificate system and the analysis of students' learning situation, it should actively explore the course reform of "course and certificate integration" teaching with enterprises. According to the post skill requirements of enterprises, students can obtain the corresponding vocational skill certificates in different levels and stages, thereby realizing the comprehensive improvement from BIM model cognition to application. Accordingly, the corresponding relationship between the requirements of BIM preliminary, intermediate and advanced certificates and professional courses was analyzed, and the corresponding course system and framework of building engineering technology major were reconstructed [2]. The corresponding relationships between the preliminary, intermediate and advanced certificates and courses are shown in Table 1, Table 2, and Table 3 .

Table 1. The corresponding relationship between BIM " $1+X "$ preliminary certificates and courses

\begin{tabular}{|c|c|c|c|c|c|}
\hline $\begin{array}{l}\text { "1+X" } \\
\text { stage }\end{array}$ & $\begin{array}{l}\text { Training } \\
\text { course }\end{array}$ & $\begin{array}{c}\text { Course capability } \\
\text { target }\end{array}$ & $\begin{array}{c}\text { Corresponding to the BIM } \\
\text { capability target }\end{array}$ & $\begin{array}{l}\text { Support } \\
\text { software }\end{array}$ & $\begin{array}{c}\text { Case } \\
\text { platform }\end{array}$ \\
\hline \multirow{2}{*}{$\begin{array}{l}\text { Preliminary } \\
\text { modeling } \\
\text { stage }\end{array}$} & $\begin{array}{c}\text { BIM } \\
\text { modeling }\end{array}$ & $\begin{array}{l}\text { Building and } \\
\text { structural model } \\
\text { modeling } \\
\text { capability }\end{array}$ & $\begin{array}{l}\text { Familiar with BIM concepts and } \\
\text { relevant standards; familiar with } \\
\text { Revit software interface operation } \\
\text { commands; master Revit software } \\
\text { components familiar with drawing } \\
\text { deepening methods }\end{array}$ & Revit & \multirow{2}{*}{$\begin{array}{c}\text { Student } \\
\text { apartment } \\
\text { dorm } \\
\text { building } \\
\text { project }\end{array}$} \\
\hline & $\begin{array}{l}\text { Building } \\
\text { construction } \\
\text { and map } \\
\text { recognition }\end{array}$ & $\begin{array}{l}\text { Building and } \\
\text { structural modeling } \\
\text { capability and Map } \\
\text { recognition } \\
\text { capability }\end{array}$ & $\begin{array}{l}\text { Master the three-dimensional } \\
\text { expression methods of positive } \\
\text { projection, axial measurement } \\
\text { projection, perspective projection } \\
\text { and body shape; master the reading } \\
\text { and drawing methods of } \\
\text { construction engineering drawings }\end{array}$ & $\begin{array}{c}\text { Revit, } \\
\text { AUTOCAD }\end{array}$ & \\
\hline
\end{tabular}

Table 2. The corresponding relationship between BIM " $1+X "$ intermediate certificates and courses

\begin{tabular}{|c|c|c|c|c|c|}
\hline $\begin{array}{l}\text { "1+X" } \\
\text { stage }\end{array}$ & $\begin{array}{c}\text { Training } \\
\text { course }\end{array}$ & $\begin{array}{c}\text { Course capability } \\
\text { target }\end{array}$ & $\begin{array}{c}\text { Corresponding to the BIM } \\
\text { capability target }\end{array}$ & $\begin{array}{l}\text { Support } \\
\text { software }\end{array}$ & $\begin{array}{c}\text { Case } \\
\text { platform }\end{array}$ \\
\hline \multirow[t]{2}{*}{$\begin{array}{l}\text { Intermediate } \\
\text { engineering } \\
\text { management } \\
\text { application } \\
\text { stage }\end{array}$} & $\begin{array}{c}\text { Construction } \\
\text { engineering } \\
\text { measurement } \\
\text { and } \\
\text { valuation }\end{array}$ & $\begin{array}{l}\text { The ability of } \\
\text { reinforcing bar } \\
\text { sampling, civil } \\
\text { engineering calculation } \\
\text { and civil engineering } \\
\text { valuation; independently } \\
\text { completing the } \\
\text { preparation of } \\
\text { construction project } \\
\text { budget }\end{array}$ & $\begin{array}{l}\text { Familiar with the valuation } \\
\text { principle of construction } \\
\text { engineering; proficient in the } \\
\text { application of construction } \\
\text { engineering budget quota; } \\
\text { master the calculation method } \\
\text { of construction engineering } \\
\text { quantity; master the content } \\
\text { and calculation method of } \\
\text { construction engineering cost, } \\
\text { etc. }\end{array}$ & $\begin{array}{c}\text { GTJ volume } \\
\text { calculation } \\
\text { software, Luban } \\
\text { Master } \\
\text { (TJ), Luban } \\
\text { Master (GJ) }\end{array}$ & \multirow[t]{2}{*}{$\begin{array}{c}\text { Yellow } \\
\text { River } \\
\text { Delta } \\
\text { talent } \\
\text { training } \\
\text { center } \\
\text { project }\end{array}$} \\
\hline & $\begin{array}{l}\text { Construction } \\
\text { technology }\end{array}$ & $\begin{array}{l}\text { Capacity of drawing } \\
\text { review and technical } \\
\text { disclosure during } \\
\text { construction stage }\end{array}$ & $\begin{array}{l}\text { Capacity of three-dimensional } \\
\text { visual simulation and } \\
\text { animation production of the } \\
\text { construction process }\end{array}$ & $\begin{array}{c}\text { Revit, } \\
\text { nawisworks, } \\
\text { Shanghai Weiqi } \\
\text { Construction } \\
\text { Virtual } \\
\end{array}$ & \\
\hline
\end{tabular}




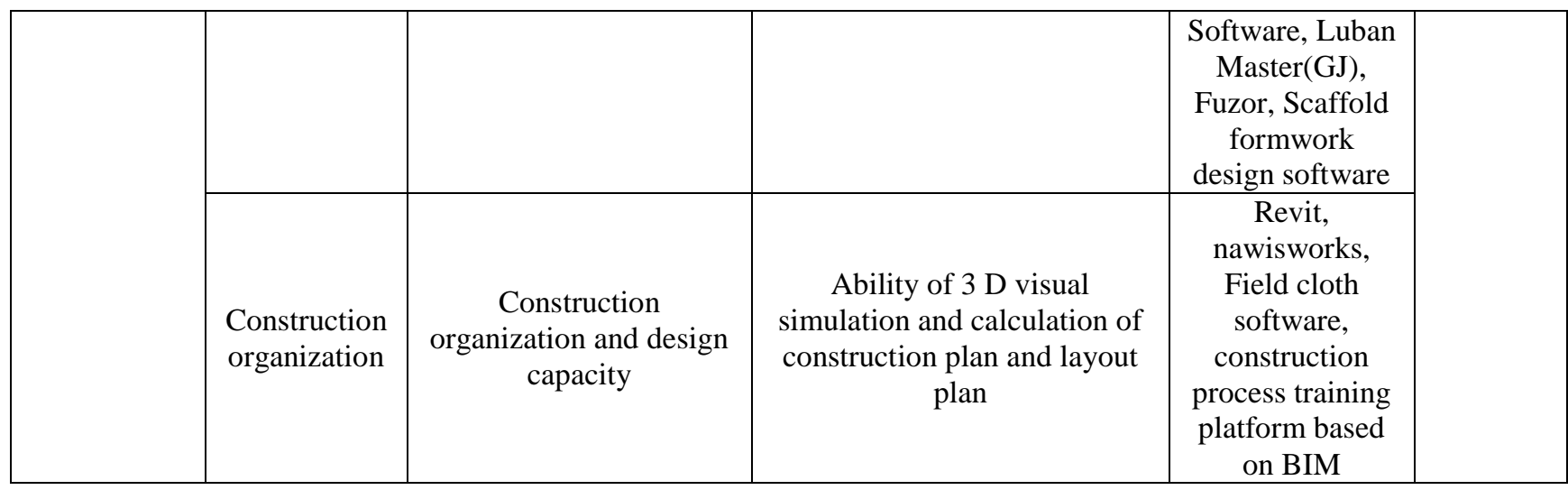

Table 3. The corresponding relationship between BIM "1+X" advanced certificates and courses

\begin{tabular}{|c|c|c|c|c|c|}
\hline "1+X" stage & $\begin{array}{l}\text { Training } \\
\text { course }\end{array}$ & $\begin{array}{c}\text { Course } \\
\text { capability target }\end{array}$ & $\begin{array}{l}\text { Corresponding to the } \\
\text { BIM capability target }\end{array}$ & Support software & $\begin{array}{c}\text { Case } \\
\text { platform }\end{array}$ \\
\hline \multirow{4}{*}{$\begin{array}{c}\text { Advanced } \\
\text { comprehensive } \\
\text { application and } \\
\text { management } \\
\text { stage }\end{array}$} & $\begin{array}{l}\text { Construction } \\
\text { project } \\
\text { schedule } \\
\text { management }\end{array}$ & $\begin{array}{l}\text { Preparation and } \\
\text { adjustment } \\
\text { capacity of the } \\
\text { construction } \\
\text { schedule }\end{array}$ & $\begin{array}{l}\text { Dynamic construction } \\
\text { progress simulation } \\
\text { (including progress and } \\
\text { resource information) } \\
\text { and progress } \\
\text { adjustment capacity } \\
\text { corresponding to model } \\
\text { change }\end{array}$ & $\begin{array}{l}\text { Project, Glodon zebra } \\
\text { schedule }\end{array}$ & \multirow{4}{*}{$\begin{array}{l}\text { Project cases } \\
\text { provided by } \\
\text { Binzhou } \\
\text { construction } \\
\text { industry } \\
\text { modernization } \\
\text { vocational } \\
\text { education } \\
\text { union, the } \\
\text { project case } \\
\text { for the BIM } \\
\text { software } \\
\text { platform }\end{array}$} \\
\hline & $\begin{array}{l}\text { Construction } \\
\text { engineering } \\
\text { safety } \\
\text { management }\end{array}$ & $\begin{array}{c}\text { Safety } \\
\text { management } \\
\text { capability }\end{array}$ & $\begin{array}{c}\text { Safety disclosure } \\
\text { visualization } \\
\text { simulation, process } \\
\text { problems and model } \\
\text { capabilities }\end{array}$ & $\begin{array}{c}\text { BIMVR safety } \\
\text { education and safety } \\
\text { module of } \\
\text { construction process } \\
\text { training platform } \\
\text { based on BIM }\end{array}$ & \\
\hline & $\begin{array}{l}\text { Construction } \\
\text { engineering } \\
\text { quality } \\
\text { management }\end{array}$ & $\begin{array}{l}\text { Quality control } \\
\text { capability, quality } \\
\text { acceptance } \\
\text { capability, quality } \\
\text { problem analysis } \\
\text { and rectification } \\
\text { capability }\end{array}$ & $\begin{array}{l}\text { Visual association and } \\
\text { analysis of process } \\
\text { problems and models, } \\
\text { problem and model } \\
\text { comparison, collision } \\
\text { inspection and } \\
\text { optimization } \\
\text { capabilities } \\
\end{array}$ & $\begin{array}{l}\text { Revit teaching } \\
\text { version, nawisworks, } \\
\text { construction process } \\
\text { training platform } \\
\text { quality module based } \\
\text { on BIM }\end{array}$ & \\
\hline & $\begin{array}{c}\text { Construction } \\
\text { engineering } \\
\text { data } \\
\text { management }\end{array}$ & $\begin{array}{l}\text { Data writing and } \\
\text { archiving } \\
\text { capability }\end{array}$ & $\begin{array}{l}\text { Information and model } \\
\text { association capabilities }\end{array}$ & $\begin{array}{c}\text { BIM5D, Luban } \\
\text { workshop and } \\
\text { infrastructure } \\
\text { construction, Luban } \\
\text { collaboration } \\
\end{array}$ & \\
\hline
\end{tabular}

\subsection{Colleges and enterprises jointly built a comprehensive training platform based on BIM construction process}

According to the building project procedures, typical construction tasks are selected according to the progressive links from BIM model creation, professional application to comprehensive management. Relying on the unified BIM model, the corresponding training resources are constructed, and the comprehensive training platform for the whole process of building technology and management is developed. The course and building procedure are corresponded and connected as a whole, and the course resources are attached to the platform for sequencing, thus opening the channel between BIM single skills and achieving the goal of improving comprehensive skills [1]. The module composition of the training platform is shown in Table 4. 
Table 4. Typical task list of BIM comprehensive training platform based on construction process

\begin{tabular}{|c|c|c|c|c|c|}
\hline Number & $\begin{array}{l}\text { Construction } \\
\text { procedure }\end{array}$ & Specific content & \multicolumn{2}{|c|}{ Corresponding course } & $\begin{array}{l}\text { Simulation } \\
\text { training } \\
\text { platform }\end{array}$ \\
\hline \multirow{4}{*}{1} & \multirow{4}{*}{$\begin{array}{l}\text { Engineering } \\
\text { preparation }\end{array}$} & BIM model creation & \multicolumn{2}{|c|}{ BIM modeling } & \multirow{11}{*}{$\begin{array}{c}\text { BIM } \\
\text { comprehensive } \\
\text { practical } \\
\text { training } \\
\text { platform }\end{array}$} \\
\hline & & Drawing joint review & \multicolumn{2}{|c|}{$\begin{array}{c}\text { Building drawing recognition and } \\
\text { structure, flat method recognition drawing }\end{array}$} & \\
\hline & & $\begin{array}{c}\text { Construction } \\
\text { organization design } \\
\text { preparation } \\
\end{array}$ & \multicolumn{2}{|c|}{$\begin{array}{l}\text { Construction organization and } \\
\text { management }\end{array}$} & \\
\hline & & $\begin{array}{l}\text { Construction drawing } \\
\text { budget }\end{array}$ & \multicolumn{2}{|c|}{$\begin{array}{c}\text { Measurement and valuation of construction } \\
\text { engineering }\end{array}$} & \\
\hline \multirow{4}{*}{2} & \multirow{4}{*}{$\begin{array}{l}\text { Construction } \\
\text { engineering }\end{array}$} & $\begin{array}{c}\text { Foundation engineering } \\
\text { construction }\end{array}$ & \multirow{4}{*}{$\begin{array}{l}\text { Technical part: } \\
\text { engineering } \\
\text { measurement, } \\
\text { construction } \\
\text { technology, BIM } \\
\text { professional } \\
\text { application } \\
\text { (structure) }\end{array}$} & \multirow{4}{*}{$\begin{array}{l}\text { Management part: } \\
\text { construction } \\
\text { organization and } \\
\text { management, } \\
\text { project quality and } \\
\text { safety management, } \\
\text { BIM professional } \\
\text { application (project } \\
\text { management) }\end{array}$} & \\
\hline & & $\begin{array}{l}\text { Main structure } \\
\text { construction }\end{array}$ & & & \\
\hline & & Roof construction & & & \\
\hline & & $\begin{array}{l}\text { Decoration and } \\
\text { construction }\end{array}$ & & & \\
\hline \multirow{3}{*}{3} & \multirow{3}{*}{$\begin{array}{l}\text { Completion } \\
\text { acceptance }\end{array}$} & $\begin{array}{l}\text { Engineering archives } \\
\text { collection }\end{array}$ & \multicolumn{2}{|c|}{ Data management } & \\
\hline & & $\begin{array}{c}\text { Project completion and } \\
\text { settlement }\end{array}$ & \multicolumn{2}{|c|}{$\begin{array}{l}\text { Measurement and valuation of construction } \\
\text { engineering }\end{array}$} & \\
\hline & & $\begin{array}{l}\text { Project quality } \\
\text { acceptance }\end{array}$ & \multicolumn{2}{|c|}{ Project quality and safety management } & \\
\hline
\end{tabular}

\subsection{Exploring the teaching mode of "module + synthesis, level promotion"}

Based on the teaching scheme of "course and certificate integration", the teaching mode of "module + synthesis, level promotion" is actively explored. In the "module" teaching stage, the teaching content of professional courses is divided into several core teaching modules, such as construction preparation, main construction, installation engineering, comprehensive management, etc. BIM software is used to complete the training of single core module step by step according to the production process. The "comprehensive" teaching stage is the key link to cultivate students' problem-solving ability. Based on the students' learning situation and employment direction in the "module stage", students are required to complete the corresponding comprehensive projects independently by using the real projects in the school enterprise cooperation resource library, which is the training result of BIM comprehensive skills. In the process from module to synthesis, the level of training program is continuously improved, and students' skills are gradually improved from single skill to comprehensive management ability, thus achieving the improvement of employability.

\section{REFORM EFFECT AND ANALYSIS}

Through the implementation of the " $1+X "$ certificate system, the reform program of talent training for building majors is combined with professional courses and vocational skill level certificates. The teaching guiding role of " $1+X$ " certificate was brought into play, and the teaching system and training platform were constructed, which achieved the effect of "course and certificate integration" and solved many issues existing in the process of talent training [3].

\subsection{Solving the problem of talent training orientation by relying on " $1+X$ " certificate system}

The " $1+X "$ certificate system embodies the latest technology of the industry in the certificate of skill level, and transfers it to the training of talents in vocational colleges. Therefore, the vocational education talent training has been realized to better reflect the new standards and requirements of industrial development. According to the requirements of intelligent vocational skills in the construction industry, the examination content of BIM "X" certificate is integrated into the talent training program. A high skilled talent training scheme of "diploma 
course + BIM vocational skill level certificate" integration and intercommunication was formed, which expanded the space for the cultivation of compound technical talents. Furthermore, it defined the positioning of compound technical talents for the future development of intelligent information in the construction industry.

\subsection{Solving the problem of "course and certificate integration" between professional courses and " $1+X^{\prime \prime}$ certificate (BIM)}

By constructing a professional course system that integrates " $1+X "$ certificates, the connection and correspondence between vocational qualification certificate and academic certificate were realized. In the horizontal direction, different levels and different types of learning outcomes can be crossed and connected with each other. Vertically, the accumulation of learning achievements and the progressive level of vocational skills can be effectively realized [5].

In the process of implementing the $" 1+X "$ certificate system, Binzhou Polytechnic constantly adjusts the teaching course system, and uses BIM technology to carry out digital and intelligent transformation of existing professional courses. At the same time, the BIM certificate examination is implanted into the professional course. The integration of BIM skill system and professional course system forms the main course line, which realizes the integration of BIM certificate assessment and professional course teaching, as well as the integration of course system and BIM skills.

\subsection{Solving the problem of teaching model based on " $1+X$ " certificate}

Through the three stages of learning skills (BIM modeling), special management (BIM professional application) and comprehensive management (BIM comprehensive application), students realize the hierarchical talent training. In the course of learning, students go through three stages of "model creation", "model application" and "model management", and gradually transform from passive observer to model creation and user.

The professional course system is divided into several modules by integrating the teaching contents of " $1+X^{\prime \prime}$ certificate. Finally, it needs to use the comprehensive training to transform the single module skills into the students' comprehensive employability. In the process of improving the ability, the corresponding teaching mode of "module + synthesis, level promotion" was formed.

\subsection{Solving the problem of single skill training "island"}

In the stage of BIM modeling and BIM professional application, students mainly realize the special training of a single skill, which is easy to form "skill island" or "technical branch". Taking a BIM practical project as the carrier, the BIM module is implanted into the existing course, and the comprehensive training platform of course system is developed based on the " $1+X "$ certificate professional standard. The modeling, application and management skills of BIM are integrated into a unified platform and model to break through the "isolated island" of single course skill training module, and realize the breakthrough from single skill to comprehensive skill [6].

\section{CONCLUSION}

In the process of implementing " $1+\mathrm{X}$ " BIM certificate, Binzhou Polytechnic building engineering technology major constructs a course system suitable for BIM certificate by integrating BIM certificate assessment standard into professional talent training program. The BIM comprehensive training platform integrating certificate and course system has been built, and the teaching mode of "module + synthesis, level promotion" has been gradually formed. Therefore, the training level of BIM skilled talent in the specialty of building engineering technology has been comprehensively improved. It provides a reference for similar universities to carry out the reform of professional talent training under the background of " $1+X$ " certificate pilot, and offers inspiration for BIM technical talent training in the construction industry.

\section{ACKNOWLEDGMENTS}

This work was supported by Binzhou Polytechnic Teaching Reform Project (No.: xyjg2124).

\section{REFERENCES}

[1] Anderson M. Lewis. BIM Energy Modeling: Case Study of a Teaching Module for Sustainable Design and Construction Courses. Journal of Professional Issues in Engineering Education \& Practice, 2014(3).

[2] Liu Liang. Discussion on the Course Certificate Integration of BIM Primary Certificate under the "1 + X" Certificate System. Yunnan Agriculture, 2020 (11), pp. 47-51.

[3] Qian Qinmei. Applied BIM Talent Training Mode Based on "1 + X" Certificate System. Vocational Education, 2019 (10), pp. 17-21. 
[4] Chai Meijuan. Research and Practice of Building Information Model (BIM) Talent Training under the "1 $+X^{\prime \prime}$ System of Vocational Education. Vocational

Education Communication, 2019 (10), pp. 17-19.

[5] Li Xiu. Curriculum Construction of "Course Certificate Integration" in Pilot Specialty under "1 + X" Certificate System. Shanxi Architecture, 2020 (8), pp. 171-174.
[6] Yuan Jianlin. Research on the Training Mode of Engineering Cost Specialty Based on "Double Certificate Integration" [J]. Journal of Liaoning University of Technology (Social Science Edition), 2016, 18 (5): 135-138. 